\title{
The appropriate time for stem cell transplantation in albino rat with amiodarone induced lung fibrosis: histological and immunohistochemical study
}

Original Article

\author{
${ }^{1}$ Eman El Bana, ${ }^{2}$ Lamiaa Shawky \\ ${ }^{1}$ Anatomy and Embryology Department, ${ }^{2}$ Histology and Cell Biology Department, Faculty of \\ Medicine, Benha University
}

\begin{abstract}
Background: The fibrosing form of lung injury had bad progressive course and lethal outcome.

Aim of the work: This study throws light on the possible protective and/or therapeutic consequence of mesenchymal stem cell therapy in lung fibrosis induced by amiodarone in albino rat. In addition to study the possible recovery of damaged lung after amiodarone withdrawal.

Material \& Methods: Forty five adult male albino rats were divided into five equal groups. Group I (control) ; group II (amiodarone) received amiodarone $30 \mathrm{mg} / \mathrm{kg}$ orally for 6 days /week for 6 weeks, group III (withdrawal) ; group IV (early stem cell) mesenchymal stem cell was administrated after 1st dose of amiodarone therapy ; group VI (late stem cell) mesenchymal stem cell was administrated immediately after amiodarone suspension . Lung samples were processed and examined using histological and immunohistochemical techniques and the obtained data was subjected to statistical analysis. Results: Amiodarone treated group displayed obstructed bronchioles, collapsed alveoli ,inflammatory cell infiltration ,thickened interalveolar septa and pulmonary vessels wall. Increased collagen fibers deposition between alveoli and around blood vessels in addition to highly expressed caspase-3. Group III (withdrawal) recorded only mild improvement . Group IV (early stem cell therapy) showed advanced improvement of pulmonary alveolar architecture, on other side group V (late stem cell therapy)revealed moderate improvement of lung injury .

Conclusion: The majority of amiodarone lung toxicity manifestations and lung fibrosis were regressed by bone marrow derived mesenchymal stem cell (BMSCs) therapy and the best result obtained when stem cell initiated early in the development of pathogenesis.
\end{abstract}

Received: 04 August 2018, Accepted: 28 September 2018

Key Words: Amiodarone; Bone marrow derived mesenchymal stem cell; Idiopathic pulmonary fibrosis; Interalveolar septa; Stem cell.

Corresponding Author: Eman El Bana, MD, Anatomy and Embryology Department, Faculty of Medicine, Benha University, Egypt, Tel.: +20 1028003776, E-mail: emanelbana88@gmail.com

ISSN: 1110-0559, Vol. 42, No. 1

\section{INTRODUCTION}

Idiopathic Pulmonary Fibrosis is a chronic progressive (IPF) and gradually fibrotic lung disease ${ }^{[1]}$. IPF is now generally regarded as a consequence of multiple interacting genetic and environmental risk factors with repetitive local micro injuries to aging alveolar epithelium. These micro injuries stimulate fibroblasts proliferation, produces extra cellular matrix expansions and altered matrix composition and biomechanics, induces matrix produces myofibroblast and aberrant remodeling of lung interstitium ${ }^{[2]}$. Clinically, these changes can result in decreased oxygenation, respiratory failure, and eventually death ${ }^{[3]}$.

The precise pathologic mechanisms of pulmonary fibrosis are not fully understood, the ideal therapy for pulmonary fibrosis is still controversial ${ }^{[4]}$. Therapeutic options remain limited despite an increased and recent interest for new antifibrotic and anti-inflammatory ${ }^{[5]}$. Lung transplantation is considered the only effective therapy for pulmonary fibrosis ${ }^{[6]}$. However, lung transplantation has many obstacles due to organ shortages and complications resulted from long-term immunosuppression ${ }^{[7]}$. Therefore, it is necessary to uncover new effective therapies to reduce or reverse pulmonary fibrosis for reducing the morbidity and mortality associated with pulmonary fibrosis and the urgent for lung transplantation.

Amiodarone is an iodinated benzofuran derivative is the best effective agent used for the treatment of various cardiac arrhythmias especially to suppress ventricular and supraventricular tachyarrhythmias also for long-term management of atrial fibrillation and even prophylactic of its recurrence ${ }^{[8]}$. Amiodarone pulmonary toxicity is considered the most serious adverse effects of amiodarone and limits its use $\mathrm{e}^{[9]}$. Interstitial pneumonitis is the most common presentation of amiodarone-induced pulmonary disease $^{[10]}$ 
Bone marrow mesenchymal stem cells (BMSCs) are multipotent stem cells which are capable of self-renewal and can differentiate into a variety of lineages under suitable conditions. BMSCs are now extensively used in several fields help in regenerative medicine, gene therapy and tissue repair and represent an promising field research for the future ${ }^{[11]}$.

The ability to regenerate human lung tissue, if successful, would constitute a breakthrough in modern medicine. however, currently there is no effective strategy to regenerate lost bronchioles or alveoli in humans. Stem cell-based regenerative medicine holds great potential for combating tissue damage in lung diseases and other disorders by providing unlimited materials for transplant ${ }^{[12,13 ; 14]}$. Ma et al identified a previously unknown population of adult human lung stem cells, which were successfully used for generating functional human lung air exchanging units following their transplantation to a mouse model and also in a pilot human clinical trial ${ }^{[15]}$

The present study aimed to study if the time factor is important in BMSCs therapy in interstitial pulmonary fibrosis and detection the possible regression of fibrosis after recovery period.

\section{MATERIAL AND METHODS}

\section{Animals}

Forty five adult male albino rats weighing 150 200 were divided into equal five groups. The animals were obtained from the animal house, Moshtohor Faculty of Veterinary Medicine, Benha University.

Each group was kept in a separate cage under good hygienic conditions and normal balanced diet and tap water. All ethical protocols for animal treatment were followed.

\section{Drug}

Amiodarone was given in the form of tablet (Cordarone, $200 \mathrm{mg}$ ) that was obtained from Global Napi Pharmaceuticals, Egypt. The requested daily dose (30 mg/kg body weight) was dissolved in $3 \mathrm{ml}$ of $0.6 \%$ methylcellulose (vehicle of amiodarone) ${ }^{[16]}$, so rats received 4.5-6 $\mathrm{mg}$ of AMD dissolved in $3 \mathrm{ml}$ of $0.6 \%$ methylcellulose. Methylcellulose was obtained from ElGomhoria, the company for chemical and medical trading, Benha, Egypt. Systemically injected 5 x106 MSCs/100_ul in PBS (Phosphate Buffered Saline) was injected via tail vein immediately after the 1 st dose of amiodarone in group IV and after the last dose of amiodarone in group $\mathrm{V}$

\section{Experimental procedure}

Forty five adult albino male rats (Sprague-Dawley strain) were divided into five groups of nine animals in each group as following:

(1) Group I (control group) this group included 9 rats, divided into three rats for each subgroup:

a. Subgroup Ia $(n=3)$ were not received any treatment and served as negative control. b. Subgroup $\mathrm{Ib}(\mathrm{n}=3)$ received equivalent dose of methylcellulose through an orogastric tube daily for 6 weeks.

c. Subgroup Ic $(\mathrm{n}=3)$ received $0.5 \mathrm{ml}$ of buffer phosphate saline (PBS) by IV injection in the tail vein and then they were left for 6 weeks.

(2) Group II (amiodarone-treated group) included 9 rats that received the prescribed dose of amiodarone orally for 6 weeks daily and administrated by orogastric tube ${ }^{[17]}$.

(3) Group III (withdrawal group) included 9 rats that received the same dose of amiodarone for 6 weeks and then left for recovery for another 6 weeks ${ }^{[18]}$.

(4) Group IV (early SC group)included 9 rats that received AMD therapy as before in the same dose, by the same route and for the same duration ( 6 weeks) as in group II and in the 1 st day of amiodarone therapy 5 x106 MSCs/100 ul in PBS was administered by intravenous in the tail vein

(5) Group V ( late SC group ) included 9 rats that received amiodarone as before for 6 weeks, after the end of amiodarone therapy then animals were injected with bone marrow derived stem cell (BMSCs) by the same dose as in group IV in the tail vein, then rats were left for another 6 weeks following MSC therapy.

At the end of experiment, the animals Anaesthetized with an intraperitoneal injection of $75 \mathrm{mg} / \mathrm{kg}$ ketamine (intraperitoneal), sacrificed and the chest was opened and specimens of the left lung were fixed in $10 \%$ formol saline for 24 hours. Paraffin blocks were prepared and 5 $\mu \mathrm{m}$ thick sections mounted on canda balsm coated slides in case of ordinary and special staining and poly-L-lysine coated and charged slides in case of immunostaining. Subjected to the following stains.

\section{Histological stains}

Hematoxylin and eosin ${ }^{[19]}$.

Masson's trichrome stains for collagen fibers ${ }^{[20]}$.

\section{Immunohistochemical study}

Caspase stain section detection of caspase- 3 using a standard avidin-biotin peroxidase complex system according to the kit used (Neomarkers) followed by diaminobenzidine $(\mathrm{DAB})$ visualization ${ }^{[21]}$.

CD105 immunostaining ${ }^{[22]}$ the marker for or human mesenchymal stem cells. $0.1 \mathrm{ml}$ prediluted primary antibody (CD105) rabbit polyclonal $\mathrm{Ab}$ (ab27422) and incubated at room temperature in moist chamber for 30 60 minutes. Tonsil used as positive control specimens. Cellularlocalization is the cell membrane. On the other hand, one of the lung sections was used as a negative control by passing the step of applying the primary antibody.

\section{Labeling of $M S C \mathrm{~S}^{[23]}$}

MSCs were marked using $50 \mu \mathrm{m}$ iron oxide in $4 \mathrm{ml}$ 
RPMI media for $30 \mathrm{~min}$, followed by centrifugation at $2000 \mathrm{rpm}$ for $10 \mathrm{~min}$. Separate the labeled MSCs in $2 \mathrm{ml}$ RPMI me $\neg$ dia for account and markers test.

\section{Morphometric and quantitive study}

Fibrosis fraction the degree of fibrosis was quantified by analyzing slides that were stained with Masson'strichrome stain. The image analysis program was configured to detect areas of blue stained collagen within each field. At a magnification of 400, ten randomly selected constant fields per slide were selected. The fraction of blue-stained collagen areas for each field was averaged for each animal .The area fraction of fibrosis is presented as a percentage ${ }^{[24]}$.

Caspase-3 Labeling Index (caspase 3- LI ) as brown cytoplasmic staining (index for the degree of nuclear apoptosis) was quantified in ten images from ten nonoverlapping fields of each rat using Image-Pro Plus program version 6.0 (Media Cybernetics Inc., Bethesda, Maryland, USA), by the total number of evaluated cells at a magnification of 400 then multiplying by $100^{[25]}$.

\section{Statistical analysis}

All the data collected from the experiment were recorded and analyzed using Statistical Package for Social Sciences software (SPSS) Statistics software for Windows, Version 20 (IBM Corp., Armonk, NY, USA). One-way analysis of variance (ANOVA) with Post Hoc LSD test was used to compare differences among the groups. In each test, the data was expressed as the mean (M) value, standard deviation (SD) and differences were considered to be statistically significant at $P<0.01^{[26]}$.

\section{RESULTS}

\section{Haematoxylin and eosin (H\&E) stained sections}

Group I (control) lung sections revealed numerous alveolar sacs, the alveoli appeared patent with thin interalveolar septa, the bronchiole lined by simple ciliated coalminer epithelium (Fig. 1) .The lining epithelium of the alveoli was composed of squamous cells (type I pneumocytes) and large cuboidal cells (type II pneumocytes) (Fig. 2 ).

Group II (AMD) revealed distorted bronchiole with partial obliteration of the lumen by detached epithelial cells, inflammatory cellular infiltration around alveoli and in the adventitia of bronchioles were observed ,also cellular aggregates detected in marked thickened septa ,collapsed alveoli and thickened pulmonary vessel, with extravasations of red blood cells in the septa (Fig. 3).

Group III (withdrawal) showed relative improvement of lung architecture but not complete histological recovery. The lung sections revealed distended bronchioles, moderate inflammatory cell infiltration in the moderately thickened septa, around alveoli and bronchioles , thickened blood vessels wall ,focal areas of collapsed alveoli with compensatory dilatation of neighboring ones, some other alveoli are apparent normal (Fig. 4).
Group IV (early stem cell) showed that the destructive effects of AMD on the lung are deteriorated except for relative thickening of blood vessels, mild thickened interalveolar septa with mild inflammatory cell infiltration around alveoli and around the bronchiole (Fig. 5).

Group V ( late stem cell) showed moderate improvement of lung tissue ,moderate thickened IAS with moderate inflammatory cell infiltration, scattered extravasations of RBCs in the septa and thickened pulmonary blood vessels (Figs. 6).

\section{Masson's trichrome stained sections}

Group I showed minimal collagen fibers present around alveoli and the blood vessels (Fig. 7). Group II showed heavy collagen deposition around the blood vessels, bronchioles and the alveoli (Fig. 8). Group III showed moderate collagen fibers deposition around bronchioles ,alveoli and blood vessels (Fig. 9). Group IV showed minimal collagen fibers around alveoli , bronchioles and blood vessels (Fig. 10). Group V showed moderate collagen fibers deposition around bronchioles , alveoli and blood vessels (Fig.11).

\section{CD105 immunostaining sections}

The control group showed negative immunostaining for CD105 in the alveoli, bronchioles and interalveolar septa (Fig. 12). Group IV (early SC) showed squamous shaped and cuboidal positive CD105 cytoplasmic reaction in alveoli and septa (Fig. 13). Group V (late SC) showed fewer positive CD105 cells were detected in the septa and among the lining of alveoli (Fig. 14).

\section{Caspase -3 immunostaining}

Positive immunohisto-chemical staining of caspase-3 demonstrated as brown cytoplasmic staining (index for the degree of nuclear apoptosis). Group I showed very minimal cytoplasmic staining of caspase- 3 in the cytoplasm of alveolar and septa cells (Fig. 15). Group II showed highly expressed caspase- 3 reaction in the cytoplasm of pneumocyte type 1 and pneumocyte type II of alveolar and septal cells (Fig. 16). Moderate caspase-3 expression was detected group III in the cytoplasm of pneumocyte type 1 and pneumocyte type II of alveolar and septa cells (Fig. 17). Group IV showed mildly expressed caspase -3 reaction (Fig. 18) in the cytoplasm of pneumocyte type 1 and pneumocyte type II of alveolar and septa cells, while in group $\mathrm{V}$ was detected in limited areas in the cytoplasm of pneumocyte type 1 and pneumocyte type II of alveolar and septa cells (Fig. 19).

\section{Morphometric results}

The mean area $\%$ of collagen fibers deposition and of caspase-3 labeled index for all groups was represented in (Tables 1,2) and (Histograms 1,2). The collagen fiber area percentages and caspase- 3 labeled index of group II rats revealed significant increase $(P<0.01)$ compared to that of the control group .There was significant decrease 
$(P<0.01)$ in collagen fibers accumulation and in caspase-3 expression in groups IV and $\mathrm{V}$ compared to that of group II (AMD). Group III (withdrawal) showed insignificant decrease in collagen fibers accumulation and caspase-3 labeled index compared to that of group II.

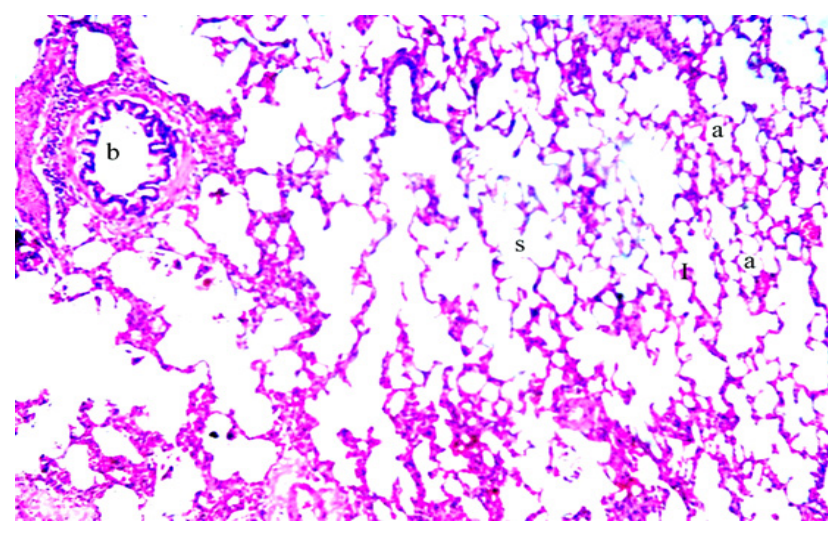

Fig. 1: A photomicrograph of a section in the lung of rat of group I (control) showing alveoli (a), thin septa (I) , alveolar sacs (s) and bronchiole(b). (H\&E x 100)

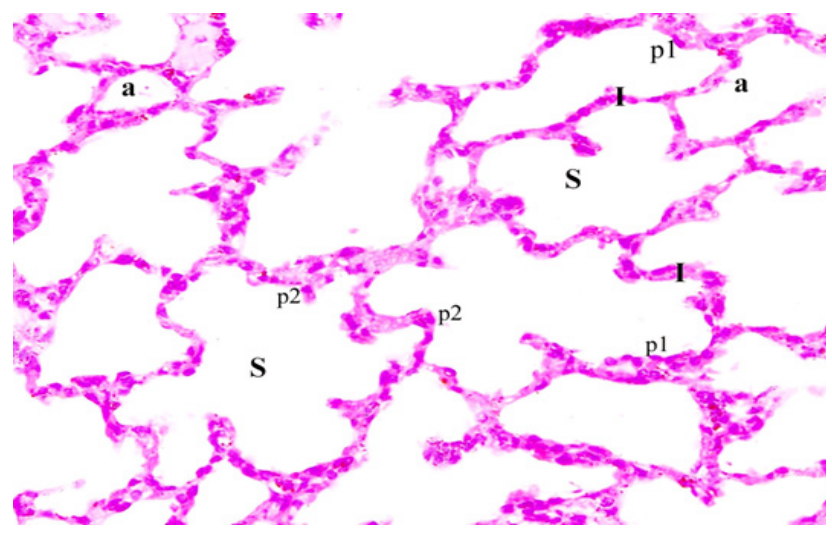

Fig. 2: A photomicrograph of a section in the lung of rat of group I (control) showing lung alveoli (a) lined with type I pneumocyte squamous cells (P1), type II pneumocyte cuboidal cells (P2), alveolar sacs (s), thin septa(I). (H\&E x 400).

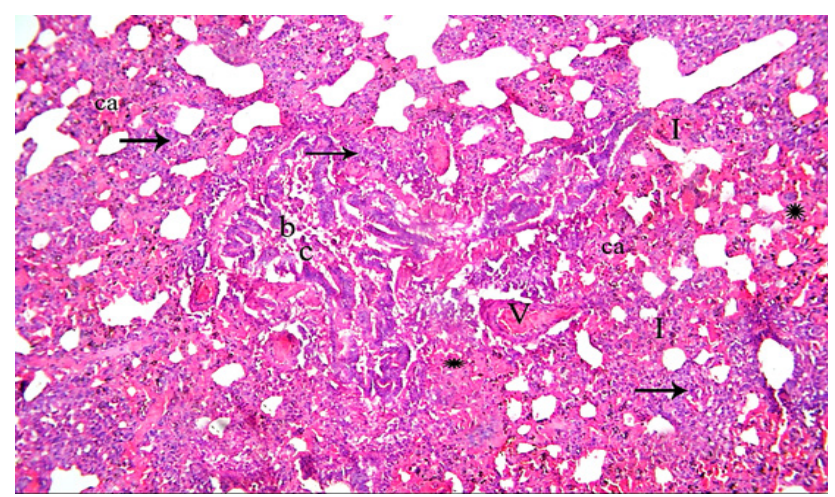

Fig. 3: A photomicrograph of a section in the lung of rat of group II (amiodarone) showing collapsed alveoli (ca) wall, heavy cellular infiltration (arrow ) in IAS and around bronchiole, markedly thickened septa (I), partially obliterated bronchiole (b) by detached epithelial cells (c) ,congested and thickened pulmonary vessel wall (V) . Note many extravasations of RBCs $(*)$ in the septa and around alveoli. (H\&E x100)

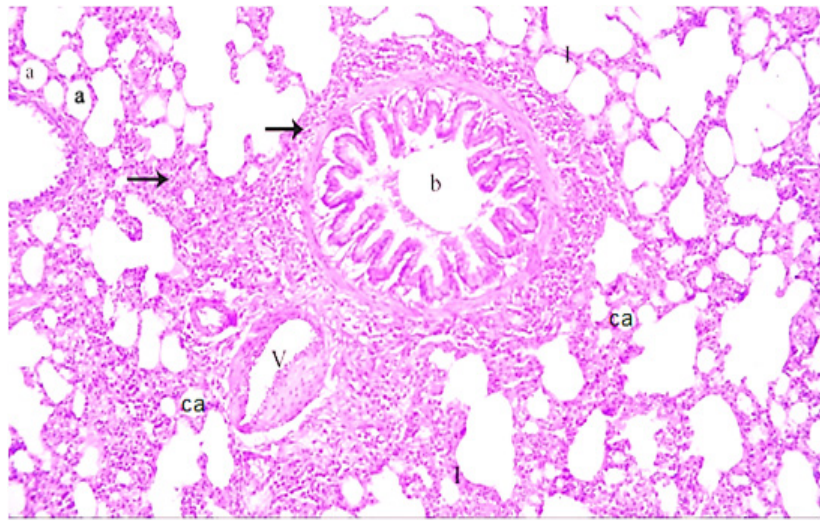

Fig. 4: A photomicrograph of a section in the lung rat of group III (withdrawal) showing focal areas of collapsed alveoli (ca), some patent alveoli (a), moderate cellular infiltration ( arrow) in the septa and the adventitia of distended bronchiole, moderate thickened septa (I) and thickened wall of pulmonary vessels (V). (H\&E x 100).

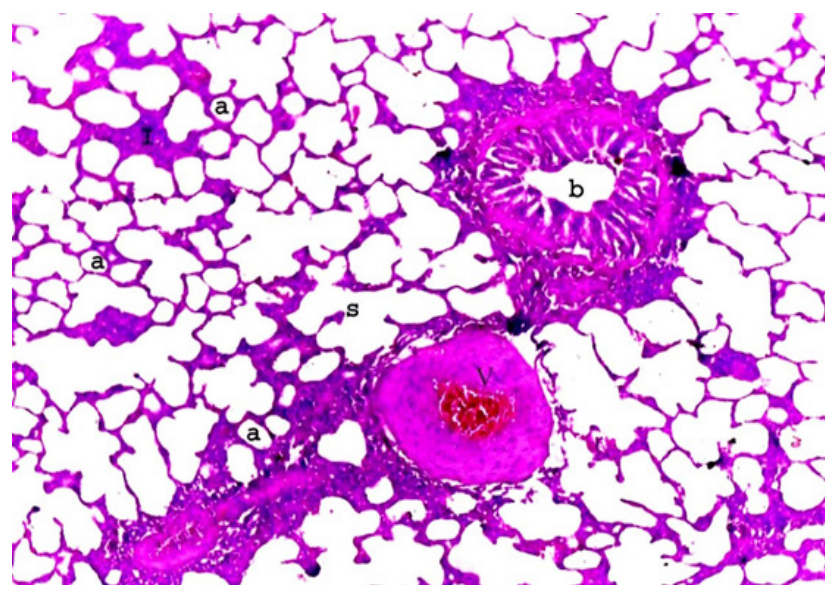

Fig. 5: A photomicrograph of a section in the lung of rat of group IV (early stem cell) showing alveoli (a) with thin septa(I) and alveolar sacs (s), normal bronchiole(b) and thickened blood vessels wall( v) (H\&E x 100)

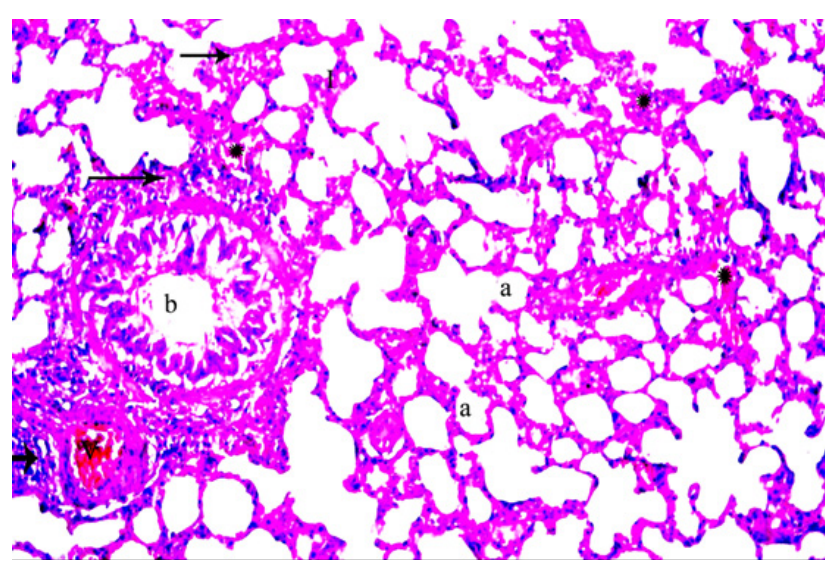

Fig. 6: A photomicrograph of a section in the lung of rat of group V (late stem cell) showing alveoli (a) with mild thickened septa(I) in between, moderate inflammatory cellular infiltration (arrow) in the septa and around adventitia of bronchiole(b) and around congested moderate thickened blood vessels( V). Note little extravasations of RBCs (*) in the septa (H\&E x100). 


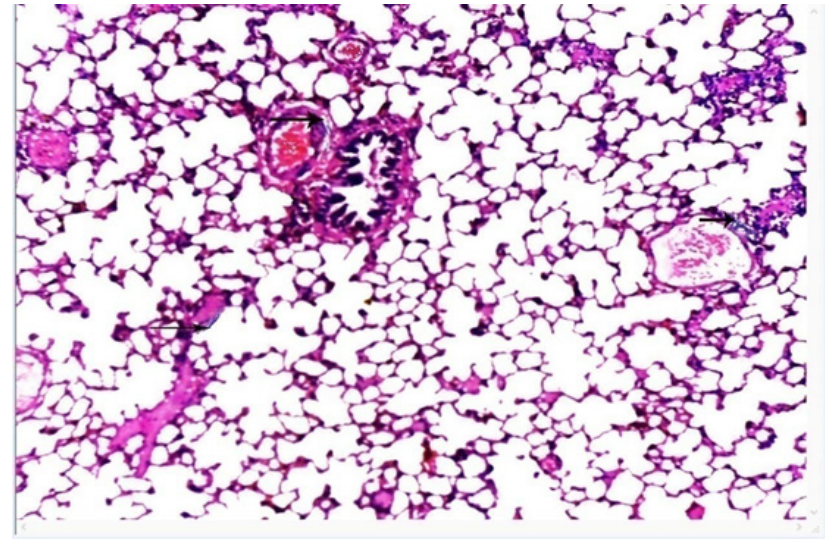

Fig.7: A photomicrograph of a section in the lung of rat of group I (control) showing little collagen fibers (arrow) around alveoli, bronchiole and blood vessel. (Masson x100).

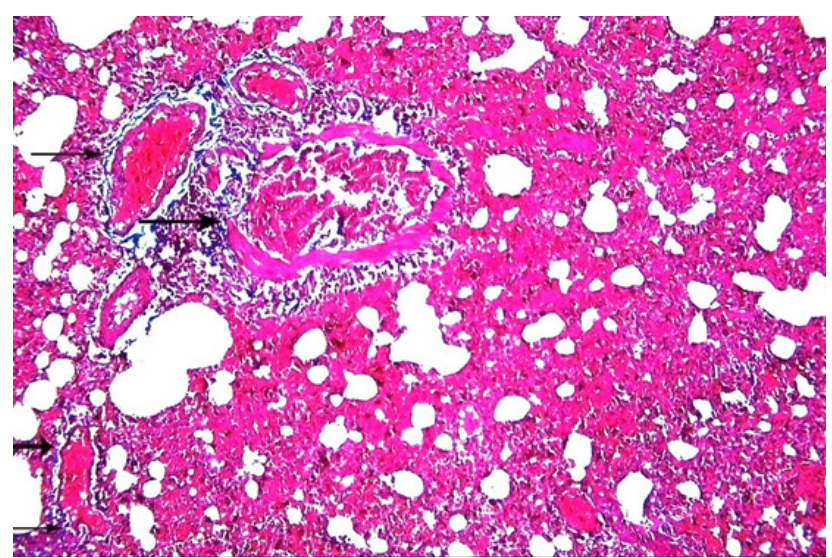

Fig. 8: A photomicrograph of a section in the lung of rat of group II (amiodarone) showing marked collagen fibers deposition (arrow) around alveoli, bronchiole and blood vessel. (Masson x 100)

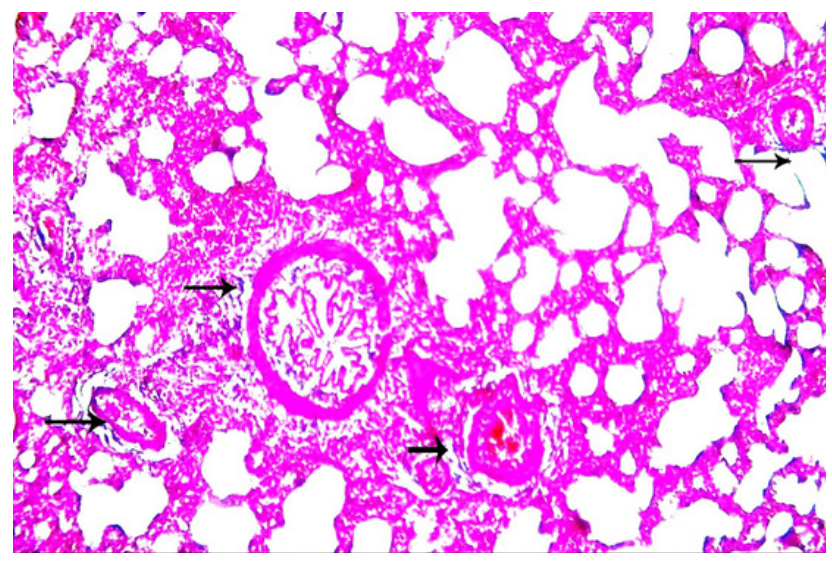

Fig. 9: A photomicrograph of a section in the lung of rat of group III (withdrawal) showing moderate collagen fibers (arrow) around bronchioles, alveoli and around blood vessel. (Masson x 100)

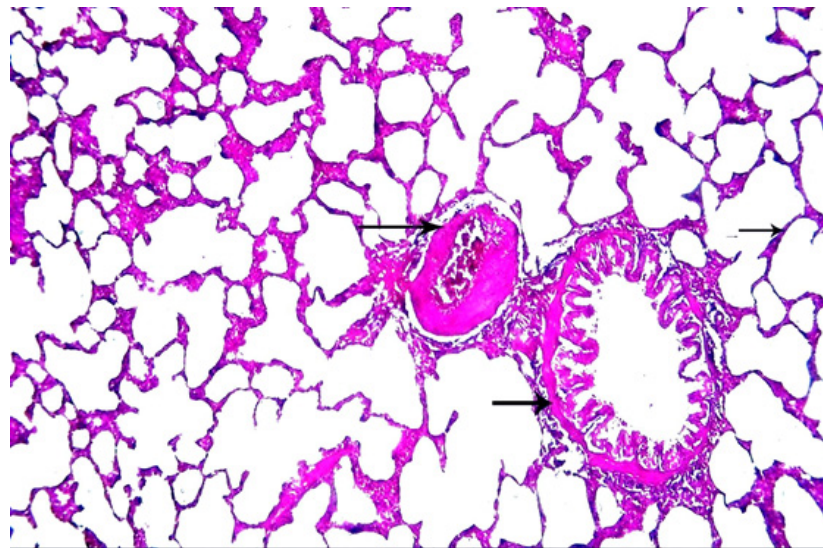

Fig.10: A photomicrograph of a section in the lung of rat of group IV (early stem cell) showing little collagen fibers (arrow) present around alveoli, bronchiole and blood vessel. (Masson x100).

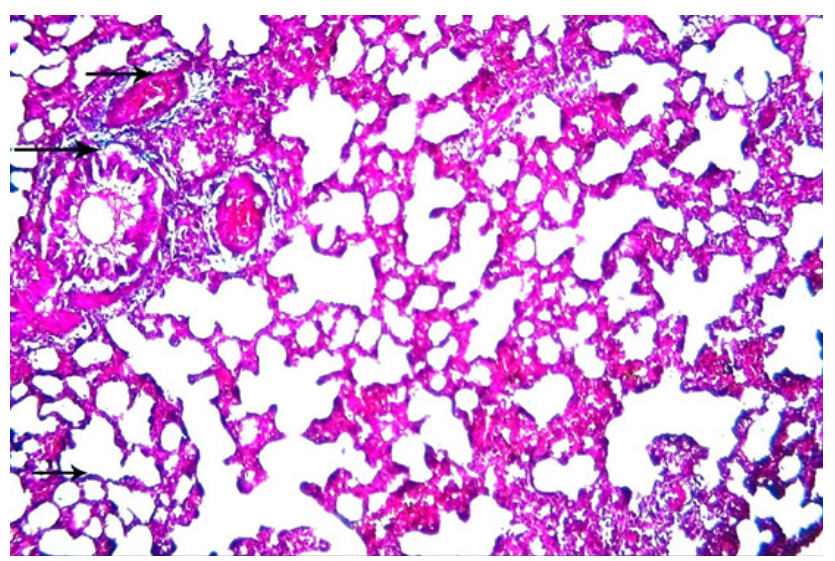

Fig. 11: A photomicrograph of a section in the lung rat of the group V (late stem cells) showing moderate collagen fibers deposition (arrow) around alveoli, bronchiole and around blood vessel . (Masson x100)

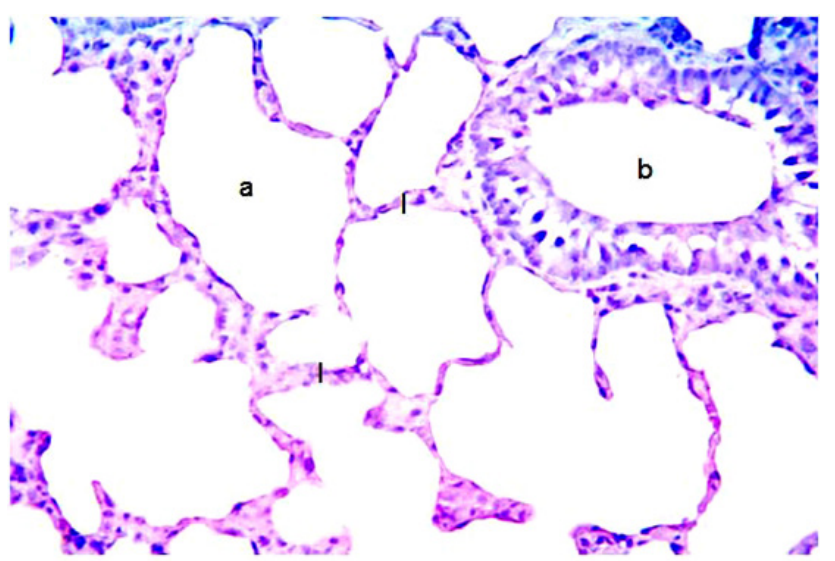

Fig. 12: A photomicrograph of a section in the lung rat of group I (control) showing negative cytoplasmic CD105 reaction in the alveoli (a), bronchi and interalveolar septa (I). (CD105 x 400). 


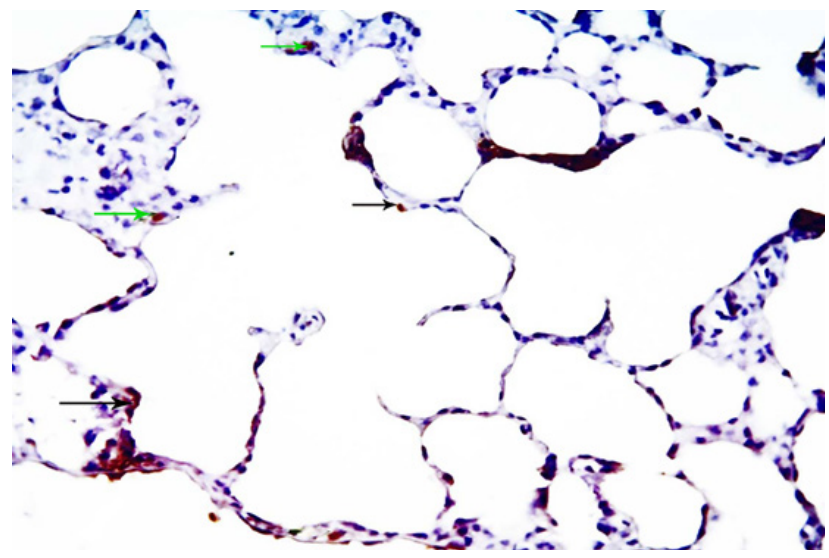

Fig.13: A photomicrograph of a section in the lung of rat of group IV (early stem cell) showing squamous shaped (black arrow) and cuboidal cells (green arrow) positive CD105 cytoplasmic reaction in alveolar lining and septal cells . (CD105 x 400).

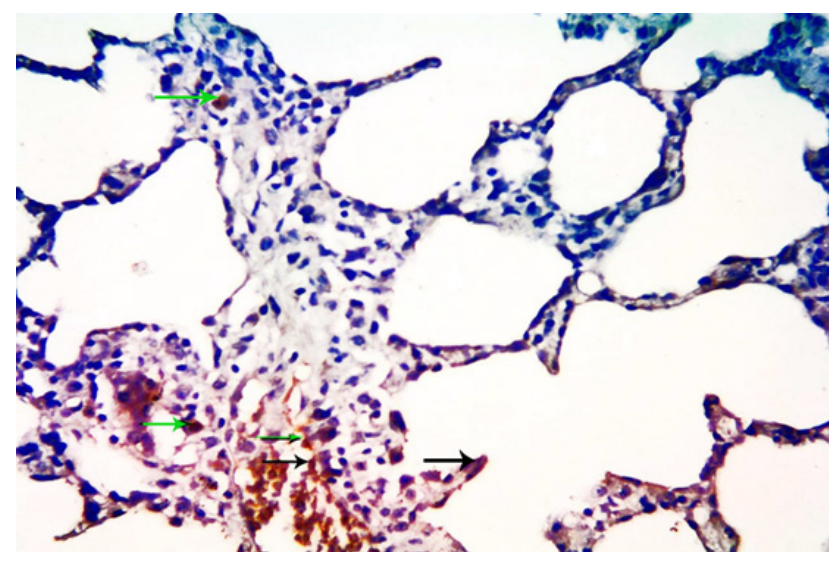

Fig. 14: A photomicrograph of a section in the lung of rat of group V (late stem cell) showing squamous shaped (black arrow) and cuboidal cells (green arrow) positive CD105 cytoplasmic reaction in alveolar lining and septal cells (CD105 x 400).

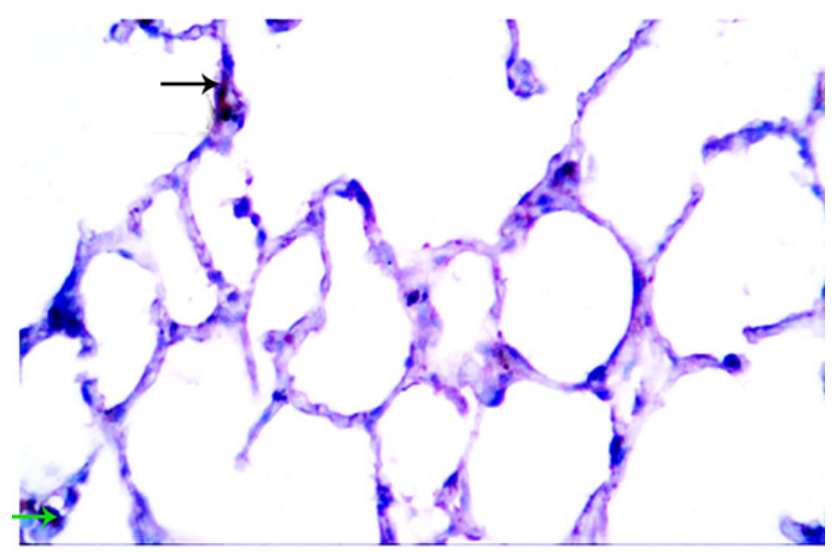

Fig. 15: A photomicrograph of a section in the lung of rat of group I (control) showing slight caspase-3 expression of the cytoplasm of pneumocyte type 1 (black arrow) and pneumocyte type II (green arrow) in the alveolar lining and septal cell [Caspase-3 x 400].

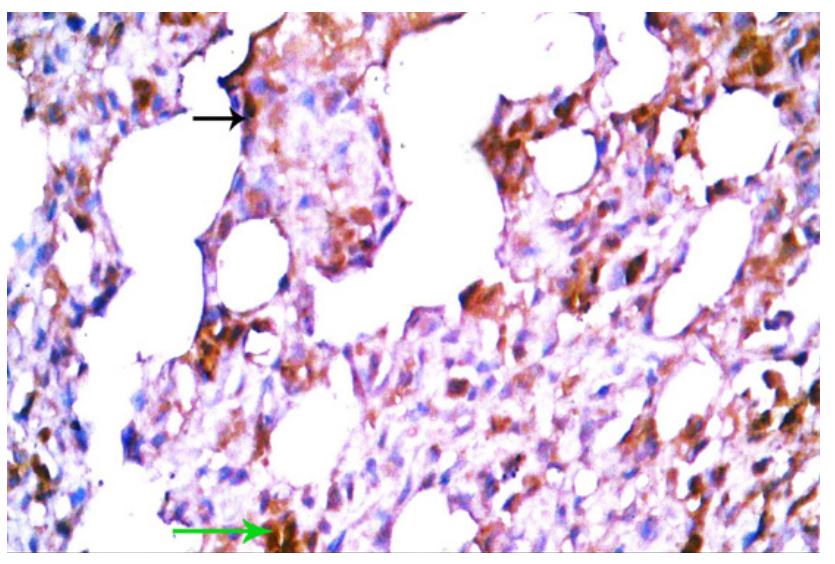

Fig.16: A photomicrograph of a section in the lung rat of group II (amiodarone) showing highly caspase-3 expression of the cytoplasm of pneumocyte type 1 (black arrow) and pneumocyte type II (green arrow) in the alveolar lining and septal cells. [Caspase- $3 \times$ 400]

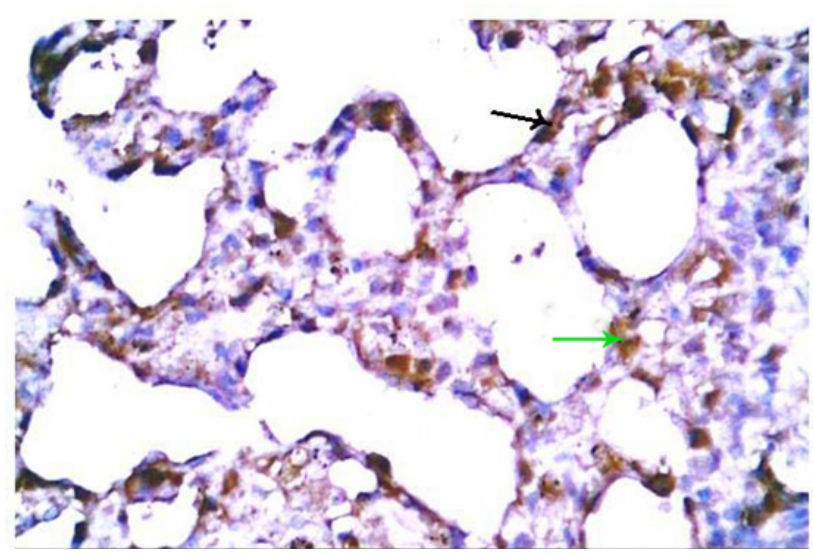

Fig. 17: A photomicrograph of a section in the lung of rat of group II (withdrawal) showing moderate caspase-3 expression of the cytoplasm of pneumocyte type 1 (black arrow) and pneumocyte type II (green arrow) in the alveolar lining and septal cells . [Caspase-3 x 400].

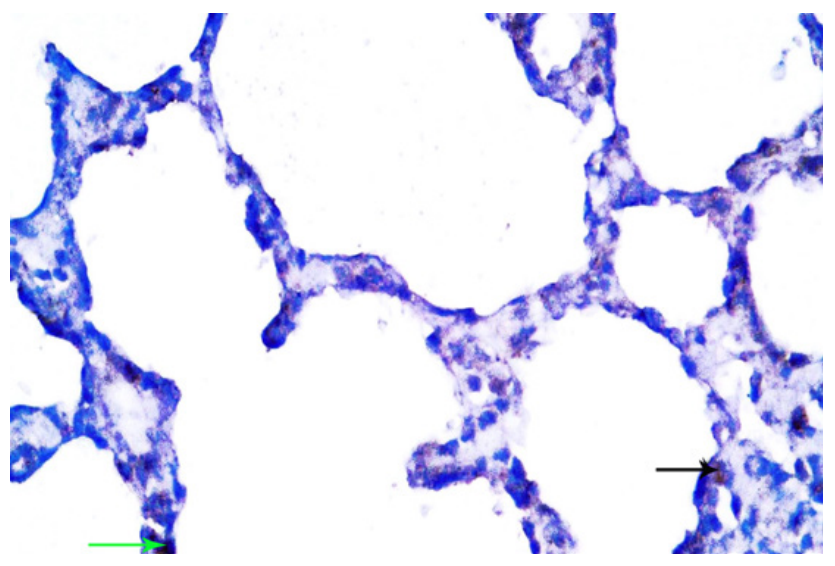

Fig. 18: A photomicrograph of a section in rat Lung of the group IV (early stem cell) showing limited caspase-3 expression (arrow) of the cytoplasm of pneumocyte type 1 (black arrow) and pneumocyte type II (green arrow) in the alveolar lining and septal cells . [Caspase-3 x 400]. 


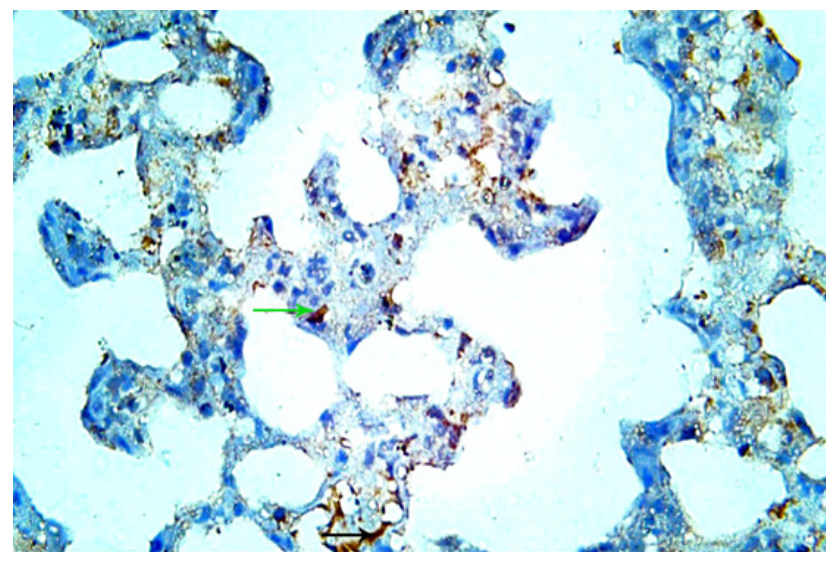

Fig.19: A photomicrograph of a section in the lung of rat of group V (late stem cell) showing mild caspase-3 expression (arrow) of the cytoplasm of pneumocyte type 1 (black arrow) and pneumocyte type II (green arrow) in the alveolar lining and septal cells .

[Caspase-3 x 400].

Table 1: showing the mean area \%, SD of collagen fibers deposition in groups I, II, II, IV and V with comparison between all groups by Post Hoc LSD test.

\begin{tabular}{|c|c|c|c|c|c|}
\hline & Group I & Group II & Group III & Group IV & Group V \\
\hline $\begin{array}{c}\text { Mean } \\
\text { area \% }\end{array}$ & $0.18 \%$ & $4.26 \%$ & $3.89 \%$ & $1.63 \%$ & $2.41 \%$ \\
\hline SD & 0.0343 & 0.2978 & 0.4017 & 0.0804 & 0.3342 \\
\hline $\begin{array}{l}\text { Significance } \\
\text { at } \mathrm{P}<0.01\end{array}$ & $\mathrm{~b}, \mathrm{c}, \mathrm{d}, \mathrm{e}$ & $\mathrm{a}, \mathrm{d}, \mathrm{e}$ & $\mathrm{a}, \mathrm{d}, \mathrm{e}$ & $\mathrm{a}, \mathrm{b}, \mathrm{c}, \mathrm{e}$ & $\mathrm{a}, \mathrm{b}, \mathrm{c}, \mathrm{d}$ \\
\hline
\end{tabular}

$\mathrm{a}=\operatorname{sig} \&$ group I $\quad \mathrm{b}=\operatorname{sig} \&$ group II $\quad \mathrm{c}=\operatorname{sig} \&$ group III $\quad \mathrm{d}=\operatorname{sig} \&$ group IV $\mathrm{e}=\operatorname{sig} \&$ group $\mathrm{V}$

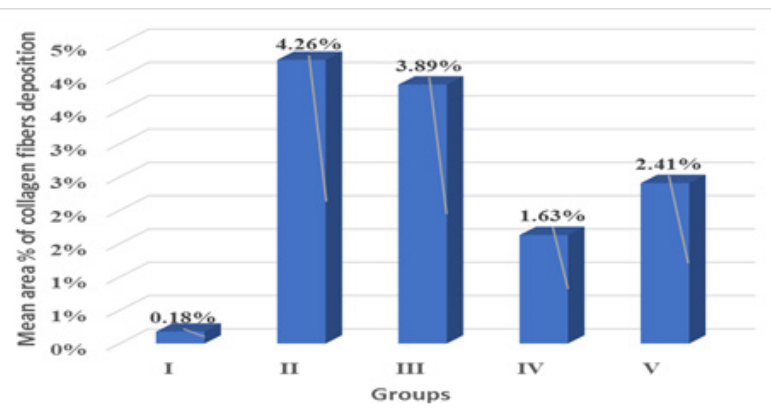

Histogram 1: Showing the mean area \% of collagen fibers deposition in groups I, II, III, IV and V.

Table 2: showing the mean area $\%$, SD of caspase-3 expression in groups I, II, III, IV and V with comparison between all groups by Post Hoc LSD test.

\begin{tabular}{cccccc}
\hline & Group I & Group II & Group III & Group IV & Group V \\
\hline $\begin{array}{c}\text { Mean } \\
\text { area \% } \\
\text { SD }\end{array}$ & $0.12 \%$ & $7.13 \%$ & $6.89 \%$ & $0.96 \%$ & $1.91 \%$ \\
$\begin{array}{c}\text { Significance } \\
\text { at P }<0.01\end{array}$ & b,c,d,e & a,d,e & a,d,e & a,b,c,e & a,b,c,d \\
\hline $\begin{array}{c}\text { a=sig \& group I } \\
\text { group IV b=sig \& group II }\end{array}$ & $\mathrm{c}=\operatorname{c}=\operatorname{sig} \&$ group V & & & & \\
group III & $\mathrm{d}=\operatorname{sig} \&$
\end{tabular}

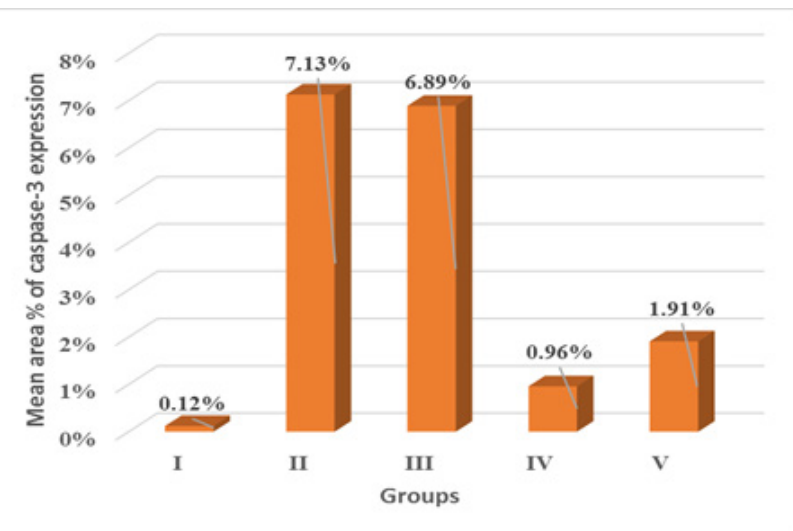

Histogram 2: Showing the mean area \% of caspase-3 expression in groups I, II, III, IV and V.

\section{DISCUSSION}

IPF is an intractable respiratory disease with poor prognosis. It has been associated with a histopathologic and/or radiologic pattern of usual interstitial pneumonia ${ }^{[27]}$. Chronic interstitial pneumonitis with pulmonary fibrosis is the most common serious pulmonary complications often associated with AMD therapy ${ }^{[28]}$.

The current study showed that administration of amiodarone altered the histological architecture of the lung and appeared in the form of damaged alveoli, focal areas of collapsed alveoli, marked thickening of septa which infiltrated by inflammatory cellular aggregates. The inflammatory cells aggregates also detected around alveoli and adventitia of bronchioles. Closer observation showed many mononuclear inflammatory cell infiltration most probably fibroblast and fibrocytes in interalveolarse pta. these destructive effects induced by AMD confirmed in the study of ${ }^{[29]}$ who study the therapeutic effect of stem cell on amiodarone induced lung fibrosis in rats. In another study on human cardiac case treated with amiodarone his pathologic examination revealed organizing pneumonia ordiffuse alveolar damage with hyaline membrane formation caused by amiodarone lung toxicity ${ }^{[30]}$.

Several mechanisms of amiodarone lung toxcity have been postulated, including direct cellular damage, induction of phospholipidosis and indirectly by an immunomlogic mechanisms by the activation of natural killer cell activity ${ }^{[31]}$. Activation of alveolar macrophages and cytokine release ${ }^{[32,33]}$. It was reported that cell death in the lungs in advanced lung disease was followed by inflammation and fibrosis ${ }^{[34]}$.

The alveolar collapse might be attributed to the imbalance between output and degradation of the surfactant. Excessive production of surfactant by hyperplastic pneumocytes type II appeared to exceed the ability of alveolar macrophages to degrade $\mathrm{it}^{[35]}$.

The present work showed administration of amiodarone led to distortion in the bronchioles and partial obliteration of the lumen by detached cells and this agreed with the 
study of ${ }^{[36]}$ on rats received amidarone daily for one month.

The occurrence of obliterative bronchiolitis explained by $^{[37]}$ who stated that the injury of bronchiolar epithelium and inflammation of subepithelial structures lead to excessive fibrocytes and fibroblast proliferation, which is due to improper tissue repair and ineffective epithelial regeneration.

In the current study, the blood vessels appeared sclerotic with marked thickened wall. Thickening of the wall of pulmonary arterioles can lead to the development of pulmonary hypertension ${ }^{[38]}$. The pulmonary blood vessels were congested with extravasations of red blood cells between alveolar cells and septa. These results were in line with ${ }^{[39]}$ who added the presence of intra-alveolar hemorrhage and formation of hyaline material and cellular aggregates of fibroblasts and macrophages in his study on rats received AMD therapy for six weeks.

The pathologic pattern of pulmonary capillaritis, is characterized by neutrophilic infiltration of the alveolar septa which sequentially leads to necrosis of these structures, loss of capillary structural integrity, and spilling of red blood cells into the alveolar space and interstitium $^{[40,41,42]}$.However diffuse alveolar hemorrhage was uncommon in AMD toxicity ${ }^{[43]}$.

The current study stated that most of the pathological changes induced by amiodarone relieved in withdrawal group but not reach to the level of complete recovery, lung tissues improved except for the presence of scattered focal areas of collapsed alveoli, moderate thickened IAS with compensatory dilatation of neighboring ones, other alveoli are normal and moderate inflammatory cellular infiltration, thickening of blood vessel wall. These data confirmed by an insignificant decrease of collagen fiber accumulation and caspase- 3 expression reaction in the recovery group when compared to AMD group.

The incomplete reversibility of the histological changes of lung tissue after amiodarone withdrawal reported in the study of ${ }^{[4]}$ and might be explained by the short time of stoppage of the amiodarone and its tendency to accumulate in the lung therapy ${ }^{[45]}$.

The incomplete reversibility of the histological changes of lung tissue after amiodarone withdrawal might be explained by the short time of stoppage of the amiodarone and its tendency to accumulate in the lung therapy ${ }^{[46]}$.

MSCs are multipotent cells capable of differentiating into a number of different cell lines and exerting antiproliferative, immunomodulatory, and antiinflammatory effects. Because of their combination of multipotency, migratory ability, and immunoprivileged state (MSCs do not express major histocompatibility factor II, making allogeneic transplant possible) $)^{[47]}$.

In the current work, it was reported that SC therapy is very effective when initiated in the start of amiodarone treatment, histopathologically the early administration of stem cell led to definite improvement of destructed lung tissue and even regaining of normal alveolar architecture except for mildly thickened septa, mild inflammatory cellular infiltration and moderately thickened blood vessels wall and this may be due to the direct relieving effect of early stem cell therapy on lung fibrosis.

On the other side late SC administration after the end of amiodarone suspension led to relative improvement but not effective like early SC administration, histopathologically lung tissue section showed moderately thickened septa with moderate inflammatory cell infiltrations and moderate thickened blood vessels walls. These results were supported by a significant decrease in the mean area percentage of both collagen fibers and caspase- 3 expression in both stem cell groups compared to group II and group III.

These important data in accordance with the study of ${ }^{[48]}$ who proved that the early administration of bone marrow-derived mesenchymal stem cells (BMSCs) were more effective on relieving of lung. However, in his study a significant reduction in the fibrotic changes with a significant decrease in mean area $\%$ of collagen fibers detected only in early SC group but not in the late SC group

These data explained in another study who reported that delaying MSC administration eliminated the ability of the cells to alter the course of disease progression, and further added that early treatment with MSCs may produce antagonists cytokines that disrupt signal pathways reducing the extent of inflammation within the lung ${ }^{[49]}$.

The study of ${ }^{[50]}$ it was documented that the timing of cell administration after lung injury can influence phenotypic conversion of donor-derived cells. Early administration of MSCs resulted in engraftment of cells as epithelial and vascular endothelial cell while administration of cells at later time points resulted in engraftment as interstitial cells

This idea is confirmed by another study discussed the effect of SC therapy on bleomycin-induced lung fibrosis and reported that the exogenous administration of MSCs was proved to attenuate bleomycin-induced lung injury by downmodulating the inflammatory responses and ameliorating fibrotic effects ${ }^{[51]}$.

In another study on the role of mesenchymal stem cell on lung fibrosis due to post exposure to irradiation stated that the infusion of BMSCs at a later stage of lung injury can be harmful and even may augment fibrosis and even further added that MSCs injected into the lung immediately after lung injury could differentiate into functional lung cells, while those injected at later stage would be involved in fibrosis

Development and differentiation of BMSCs occurred in response to mediators produced in the injured tissue ${ }^{[52]}$, so unwise to give stem cell late to those patients.

These results point to take care for the selection the optimal time for administration of stem cell and ensured that the timing factor has an important role in altering the course of fibrosis progression so it was recommended to be 
given at the beginning of pathogenesis and consequently increase the survival chances for those suffering from lung fibrosis.

\section{CONFLICTS OF INTEREST}

None declared.

\section{REFERENCES}

1. Raghu G, Collard HR., Egan JJ., Martinez FJ., Behr J, Brown, KK, Colby TV, Cordier JF, Flaherty KR, Lasky JA, Lynch DA, Ryu JH, Swigris JJ, Wells, AU, Ancochea J, Bouros D, Carvalho C, Costabel U, Ebina M, Hansell DM, Johkoh T, Kim DS, King TE Jr, Kondoh ,Y., Myers, J., Müller, N.L., Nicholson AG., Richeldi L,Selman M, Dudden RF, Griss BS, Protzko SL and Schünemann HJ. idiopathic pulmonary fibrosis: evidence-based guidelines for diagnosis and management.: Am J. Respir Crit Care Med. 183: 788-824 (2011)

2. Fingerlin TE, Murphy E, Zhang W, Peljto AL, Brown KK, Steele MP, Loyd JE, Cosgrove GP, Lynch D, Groshong S, Collard HR, Wolters PJ, Bradford WZ, Kossen K, Seiwert SD, du Bois RM, Garcia CK, Devine MS, Gudmundsson G, Isaksson HJ, Kaminski N, Zhang Y, Gibson KF, Lancaster LH, Cogan JD, Mason WR, Maher TM, Molyneaux PL, Wells AU, Moffatt MF, Selman M, Pardo A, Kim DS, Crapo JD, Make BJ, Regan EA, Walek DS, Daniel JJ, Kamatani Y, Zelenika D, Smith K, McKean D, Pedersen BS, Talbert J, Kidd RN, Markin CR, Beckman KB, Lathrop M, Schwarz MI and Schwartz DA. Genome wide association study identifies multiple susceptibility loci for Idiopathic pulmonary fibrosis Nat. Nat Genet. 2013,45(6):613-620.

3. Walsh SLF, Wells AU, Desai SR, Poletti V, Piciucchi S, Dubini A, Nunes H, Valeyre D, Brillet PY, Kambouchner M, Morais A, Pereira JM, Moura CS, Grutters JC, van den Heuvel DA, van Es HW, van Oosterhout MF, Seldenrijk CA, Bendstrup E, Rasmussen F, Madsen LB, Gooptu B, Pomplun S, Taniguchi H, Fukuoka J, Johkoh T, Nicholson AG, Sayer C, Edmunds L, Jacob J, Kokosi MA, Myers JL, Flaherty KR and Hansell DM. Multicentre evaluation of multidisciplinary team meetingagreement on diagnosis in diffuse parenchymal lung disease: a case-cohort study. Lancet Respir Med.2016;4(7):557-565.

4. Adamali HI and Maher TM. Current and novel drug therapies for idiopathic pulmonary fibrosis. Drug Des DevelTher. 2012;6:261-272.

5. CovveyJ. R. and ManclE. E., "Recent evidence for pharmacological treatment of idiopathic pulmonary fibrosis," Annals of Pharmacotherapy, vol. 48, no. 12, pp. 1611-1619, 2014.
6. Whelan TP. Lung transplantation for interstitial lung disease. Clin Chest Med. 2012;33:179-189.

7. McShane PJ and Garrity ER Jr. Minimization of immunosuppression after lung transplantation: current trends. Transpl Int. 2009;22:90-95.

8. Martino E, Bartalena L, Bogazzi F and Braverman LE . Amiodarone and the thyroid.Endocr. Rev., 2001; 22: 240-254.

9. Schwaiblmair M, Behr W, Haeckel T, Märkl B, Foerg Wand Berghaus T. Drug-induced infiltrative lung disease.Clin Res. Cardiol. 2010; 99:693-700.

10. Martin WJ and Rosenow EC .Amiodarone pulmonary toxicity: Recognition and pathogenesis (Part I). 1988 ;Chest 93:1067-74.

11. Shirong, Ni, Dexuan Wang, Xiaoxiao Qiu, Lingxia Pang, Zhangjuan Song, Kunyuan Guo: Bone marrow mesenchymal stem cells protect against. Int J Clin Exp Pathol 2015;8(7):7752-7761.

12. Ni S, Wang D, Qiu X, Pang L, Song Z and Guo $\mathrm{K}$. Bone marrow mesenchymal stem cells protect against against bleomycin-induced pulmonary fibrosis in rat by activating $\mathrm{Nrf} 2$ signaling. Int $\mathrm{J}$ ClinExpPathol ,2015; 8(7):7752-7761.

13. Yang J, Li J, Suzuki K, Liu X, Wu J, Zhang W, Ren R, Chan P, Izpisua Belmonte JC, Qu J, et al. Genetic enhancement in cultured human adult stem cells conferred by a single nucleotide recoding. Cell Res. 2017;27:1178.

14. Shi Y, Inoue H, Wu JC and Yamanaka S. Induced pluripotent stem cell technology: a decade of progress. Nat Rev Drug Discov. 2017; 16:115-130.

15. Si Wang, Jun Wu and Guang-Hui Liu. First stem cell transplantation to regenerate human lung Protein Cell. 2018 Mar; 9(3): 244-245.

16. Ma Q, Ma Y, Dai X, Ren T, Fu Y, LiuW, Han Y, Wu Y, Cheng Y and Zhang T () Regeneration of functional alveoli by adult human SOX9+ airway basal cell transplantation. Protein Cell, 2018.

17. Kolettis TM, Agelaki MG, Baltogiannis GG, Vlahos AP, Mourouzis I, Fotopoulos A and Pantos C. Comparative effects of acute vs. chronic oral amiodarone treatment during acute myocardial infarction in rats. Europace.2007;9:1099-1104.

18. Cappiello E, Boldorini R, Tosoni A, Piraneo $\mathrm{S}$, Bernasconi $\mathrm{R}$ and Raggi U. Ultrastructural evidence of thyroid damage in amiodaroneinduced thyrotoxicosis. J Endocrinol Invest ,1995; 18:862-868.

19. Freedman MD and Somberg JC. Pharmacology and pharmacokinetics of amiodarone. J ClinPharmacol, 1991; 31:1061-1069. 
20. Kiernan JA. .Histological and Histochemical methods: Theory and Practice. 3rd ed. London, New York \& New Delhi: Arnold Publisher, 2001; pp. 111-162.

21. Bancroft JD and Gamble M. Connective tissue stains. In: Theory and Practice of Histological Techniques. 6th ed. Elsevier Health Sciences, Churchill Livingstone; Edinburgh, London, Oxford, New York, Philadelphia, St Louis, Sydney and Toronto; 2008. p. 150.

22. Jackson $P$ and Blythe D.Immunohistochemical techniques. In: Suvarna SK, Layton C, Bancroft JD (eds.) Theory \& Practice of histological techniques(7thedn.) Churchill Livingstone of ElSevier, Philadelphia, USA. 2013; Ch. 18, pp 381-434.

23. Yagi H, Soto-Gutierrez A, Kitagawa Y, Tilles AW, Tompkins RG., and Yarmush ML. Bone marrow mesenchymal stromal cells attenuate organ injury induced by LPS and burn Cell Transplantepub ahead of print) Mol. Ther, 2010 ; 18: 1857-1864.

24. Riegler J, Liew A, Hynes SO, Ortega D, O’Brien T, Day RM, et al. Superparamagnetic iron oxide nanoparticle targeting of MSCs in vascular injury. Biomaterials 2013; 34:1987-1994.

25. Izbicki G, Segel MJ, Christensen TG, Conner MW, Breuer R. Time course of bleomycin-induced lung fibrosis 2002.Int. J. Exp. Pathol., 83(3): 111-119.

26. Korkolopoulou P, Oates J, Crocker J and Edwards C. p53 expression in oat and nonoat small cell lung carcinomas: correlations with proliferating cell nuclear antigen. J. Clin. Pathol.1993;46:1093-1096.

27. Dawson-Saunders B and Trapp RG. Basic and Clinical Biostatistics. 3rd ed. New York, NY: Lang Medical Books/McGraw-Hill, 2001.

28. Fujimoto H, Kobayashi $T$, and Azuma A . Idiopathic Pulmonary Fibrosis: Treatment and Prognosis Clin Med Insights CircRespirPulm Med. 2015; 9(Suppl 1): 179-185.

29. Uhal BD, Wang R, Laukka J, Zhuang J, Soledad Conrad V. and Filippatos G. Pharmacol. Toxicol., 2003;92: 81-87.

30. Zaglool SS, Zickri MB, Abd El Aziz DH, Mabrouk D and Metwally HG .Effect of stem cell therapy on amiodarone induced fibrosing interstitial lung disease in albino rat. Int. J. Stem Cells, 2011; 4(2): 133-142 .

31. Nacca $\mathrm{N}$, Bhamidipati CM, Yuhico LS, Pinnamaneni S. and Szombathy T. Severe amiodarone induced pulmonary toxicity. $\mathrm{J}$. Thorac Dis, 2012; 4(6):667-670.
32. Taylor MD, Antonini JM, Roberts JR, Leonard SS, Shi X, Gannett PM, Hubbs AF, Reasor MJ ,Taylor MD, Antonini JM, Roberts JR, Leonard SS, Shi X, Gannett P.M, Hubbs AF and Reasor MJ.Intratracheal amiodarone administration to F344 rats directly damages lung airway and parenchymal cells. Toxicol. Appl. Pharmacol., 2003; 188: 92-103.

33. Bolt MW, Racz WJ, Brien JF and Massey TE. Effects of vitamin $\mathrm{E}$ on cy4totoxicity of amiodarone and $\mathrm{N}$-desethylamiodarone in isolated hamster lung cells. Toxicology ,2001; 166:109-118.

34. Punithavathi D, Venkatesan $\mathrm{N}$ and Babu $\mathrm{M}$. Protective effects of curcumin against amiodaroneinduced pulmonary fibrosis in rats.British J. Pharmacol., 2003;139 (7): 1342-1350.

35. Larsen BT, Vaszar LT, Colby TV and Tazelaar HD. Lymphoid hyperplasia and eosinophilic pneumonia as histologic manifestations of amiodaroneinduced lung toxicity. Am J Surg Pathol, 2012; 36:509-516.

36. Nagata N, Suematsu R, Yoshii C, Miyazaki H, Sueishi $\mathrm{K}$ and Kido M. Characterization of amiodarone pneumonitis as related to inflammatory cells and surfactant apoprotein. Chest, 1997;112: 1068-1074.

37. Aboul-Fotouh GI, Zickri MB, Metwally HG, Ibrahim IR, Kamar SS and Sakr W. Therapeutic Effect of Adipose Derived Stem Cells versus Atorvastatin on Amiodarone Induced Lung Injury in Male Rat: Intern. J. Stem Cells, 2015; 8(2): 170-180.

38. Barker AF, Bergeron A, Rom WN and Hertz MI Obliter.Bronchiol., New Engl. J. Med., 2014.; 370: 1820-1828.

39. Sood BG, Wykes S, Landa M, De Jesus L and Rabah R. Expression of eNOS in the lungs of neonates with pulmonary hypertension. ExpMolPathol.2011; 90:9-12.

40. Mahdy .A.A . The Possible Ameliorative Effect of Selenium and Vitamins Combination against Amiodarone-Induced Alveolar Damage in Albino Rat: Histological and Immunohistochemical Study. Journal of American Science. 2014;10(4s), 61-71.

41. Collard HR., King TE Jr and Schwarz MI . Diffuse alveolar hemorrhage and rare infiltrative disorders of the lung. In: Textbook of Respiratory Medicine (Broaddus, V.C., Mason, R.J., Ernst, J.D., Lazarus, S.C., King, T.E. Jr., Murray, J.F., Nadel, J.A., Slutsky, A.S., Gotway, M.B. eds.), 6thedision. Elsevier, New York 2016; pp. 1207

42. Colby TV, Fukuoka J, Ewaskow SP, Helmers R and Leslie KO. Pathologic approach to pulmonary hemorrhage. Ann DiagnPathol 2001;5:309-19. 
43. Dhillon SS, Singh D, Doe N, Qadri AM, Ricciardi $\mathrm{S}$ and Schwarz MI: Diffuse alveolar hemorrhage and pulmonary capiliritis due to propylthiouracil. Chest 1999; 116:1485-1488

44. Borders CW 3rd, Bennett S, Mount C and Claassen SL. A rare case of acute diffuse alveolar hemorrhage following initiation of amiodarone: a case report. Mil Med. 2012; 177:118-120

45. Zidan, R. A. Effect of long-term administration of amiodarone on rat lung and the possible protective role of vitamin E: a histological and immunohistochemical study. The Egyptian J. Histol., 2010; 34: 117-127.

46. Kaushik S, Hussain A, Clarke P and Lazar HL. Acute pulmonary toxicity after low-dose amiodarone therapy.Ann Thorac Surg. 2001;72:1760-1761.

47. Le Blanc K, Frassoni F, Ball L, Locatelli F, RoelofsH, Lewis I, Ichikado K, Ando $\mathrm{M}$ and Nakamura H. Mesenchymal stem cells for treatment of steroid-resistant, severe, acute graftversus-host disease: a phase II study. Lancet. 2008; 371:1579-1586.
48. Sabry MM, Elkalawy SA, Abo-Elnour RKA and Abd-El-Maksod DF. Histolgical AND Immunohistochemical Study on the Effect of Stem Cell Therapy on Bleomycin Induced Pulmonary Fibrosis in Albino Rat :Intern . Stem Cells, 2014; 7(1): 33-42

49. Ortiz LA, Gambelli F, McBride C, Gaupp D, Baddoo M, Kaminski $\mathrm{N}$ and Phinney DG. Mesenchymal stem cell engraftment in lung is enhanced in response to bleomycin exposure and ameliorates its fibrotic effects. Proc. Natl. Acad. Sci. USA, 2003 ;100: 8407-8411.

50. Sueblinvong V and Weiss DJ. Cell therapy approaches for lung diseases: current status. CurrOpinPharmacol.2009; 9:268-273.

51. Malgieri A, Kantzari E, Patrizi MP and Gambardella S. Bone marrow and umbilical cord blood human mesenchymal stem cells: state of the art. Int J ClinExp Med. 2010;3:248-269.

52. Yan X, Liu Y, Han Q, Jia M, Liao L, Qi M and Zhao RC. Injured microenvironment directly guides the differentiation of ngrafted FLK $-(+)$ mesenchymal stem cell in the lung . ExpHematol. 2007; 35(9):1466-1475. 


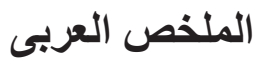

\title{
الوقت المناسب لزرع الخلايا الجذعية في الجرذان البيضاء مع التليف الرئوي المستحث بعقار

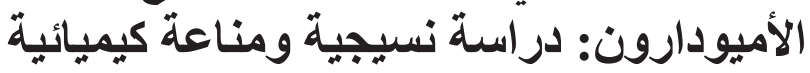

\author{
ايمان على السيد البنا'، لمياء محمد شوقى' النّا

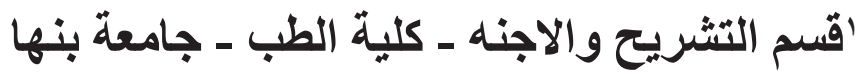 \\ بقسم الأنسجة وبيولوجيا الخلية ـ كلية الطب - جامعة بنها
}

المقدمة: الاصـابة الليفية فى الرئة لها مسار تدريجي سيئ ونتائج مميتة.

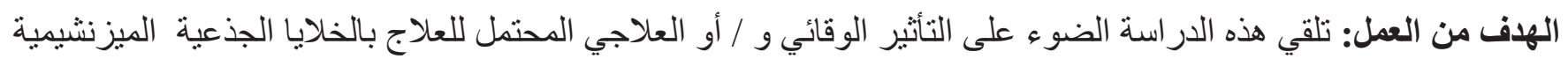

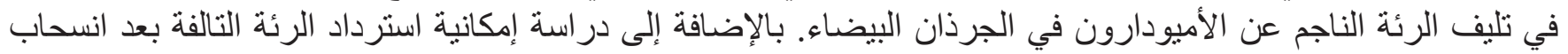
الأميودارون.

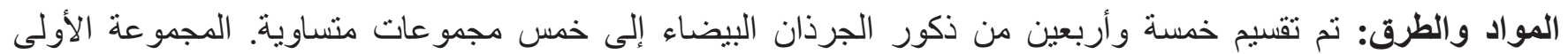

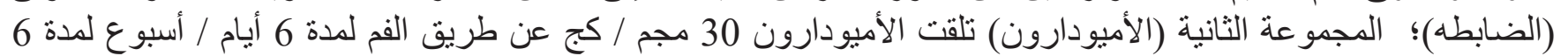

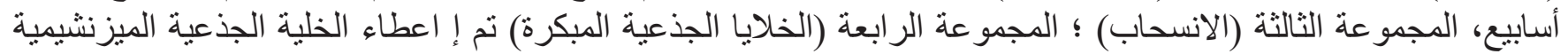

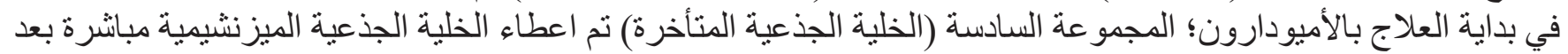

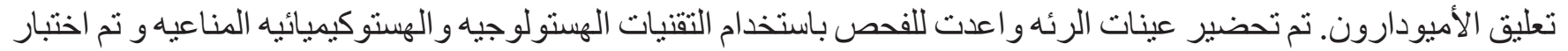
البيانات التي تم الحصول دارن عليها لتحليل إحصائي.

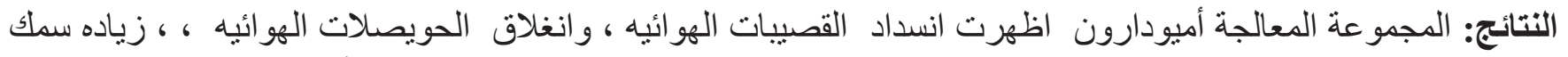

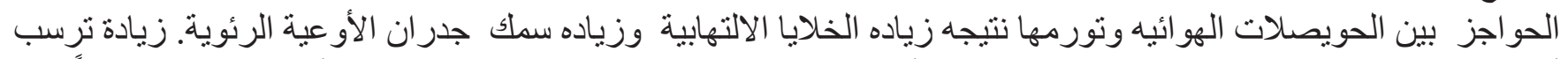

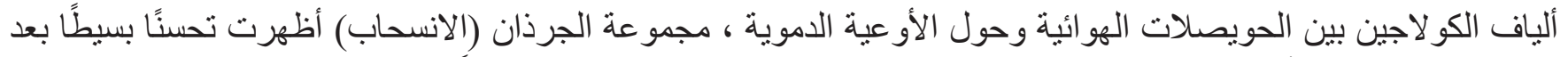

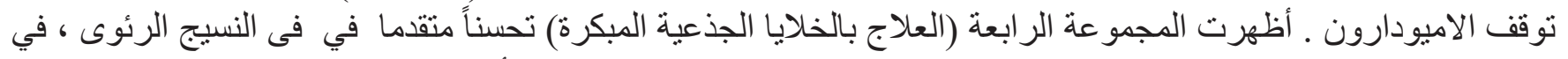
حين تم الكثف عن تحسن معتدل في المجمو عة الخامسة العنة (العلاج بالخلايا الجذعية المتأخرة).

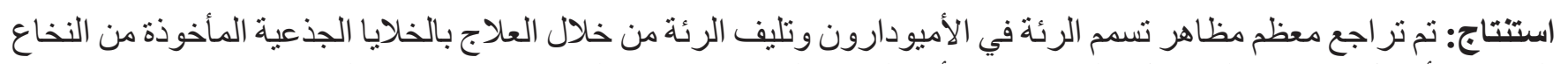
العظمي و أفضل نتيجة تم الحصول عليها عندما بدأت الخلايا الجذعية في مرحلة مبكرة من تطور المرض. 